STANISŁAWA BYRA

MONIKA PARCHOMIUK

Wydział Pedagogiki i Psychologii

Uniwersytet Marii Curie-Skłodowskiej

Lublin
Forum Pedagogiczne 2016/1

Wpłynęło: 21.11.2015

Zatwierdzono do druku: 27.02.2016

\title{
OBRAZ SIEBIE I MAŁŻEŃSTWA U WSPÓŁMAŁŻONKÓW OSÓB Z NIEPEŁNOSPRAWNOŚCIĄ RUCHOWĄ. PERSPEKTYWA STYGMATYZACJI PRZENIESIONEJ
}

Streszczenie: Przedmiotem artykułu jest analiza wyników badań własnych, dotyczących znaczenia stygmatyzacji przeniesionej dla obrazu siebie oraz satysfakcji małżeńskiej partnerów osób z niepełnosprawnością ruchową. Uwzględniając globalny poziom stygmatyzacji przeniesionej, postrzeganej oraz odczuwanej, przeanalizowano jego znaczenie dla wybranych własności obrazu siebie pełnosprawnych współmałżonków oraz doświadczanej przez nich satysfakcji ze związku w zakresie poszczególnych jej aspektów oraz wskaźnika globalnego. W badaniach wzięło udział 85 osób pełnosprawnych. Materiał zebrano za pomocą Kwestionariusza Stygmatyzacji Przeniesionej własnego autorstwa, Skali Samooceny Fittsa oraz Kwestionariusza Dobranego Małżeństwa Plopy. Ustalono, że poziom stygmatyzacji przeniesionej w obu jej wymiarach różnicuje istotnie własności obrazu siebie badanych oraz ich satysfakcję małżeńską. Osoby o wysokim poziomie stygmatyzacji ujawniły relatywnie najwyższy poziom samokrytycyzmu i identyfikacji z własnym Ja, ale również najwyższe wartościowanie poszczególnych sfer Ja. Najkorzystniejszy obraz związku małżeńskiego, ze stosunkowo najwyższym poczuciem intymności oraz podobieństwa, a przy tym najniższym rozczarowaniem, odnotowano u osób mających niski poziom stygmatyzacji w obu jej wymiarach.

Słowa kluczowe: stygmatyzacja, stygmatyzacja przeniesiona, obraz siebie, satysfakcja małżeńska, niepełnosprawność ruchowa

\section{Wprowadzenie}

Zjawisko konsekwencji nabycia niepełnosprawności ruchowej poddawane jest analizie $\mathrm{z}$ różnych punktów widzenia. Podstawowa płaszczyzna zarówno teoretycznych, jak i empirycznych rozstrzygnięć koncentruje się na wymiarze jednostkowym i społecznym. Wymiar jednostkowy zawierający skutki, jakich doświadcza jednostka w związku z nabyciem trwałego uszkodzenia narządu ruchu, pozostaje 
w ścisłej relacji z aspektem społecznym, obrazującym zmiany w pełnionych rolach i uczestnictwie w poszczególnych przejawach życia społecznego. Jednostkowy i społeczny zakres konsekwencji jest rozległy, odnosi się nie tylko do osoby, która nabywa trwałej niepełnosprawności ruchowej, ale również do jej najbliższego otoczenia. W literaturze ostatnich lat coraz szerzej omawia się znaczenie nabytej niepełnosprawności jednostki dla psychospołecznego funkcjonowania osób pozostających z nią w bezpośredniej relacji, w tym partnerów, małżonków, opiekunów. Jedną z perspektyw, w obrębie której rozpatrywane są doświadczenia małżonków/ partnerów osób z niepełnosprawnością, jest stygmatyzacja. Przyjmując znaczenie nakreślone przez Ervinga Goffmana (2007), analizuje się stygmatyzujące postrzeganie osób, będących w bliskich relacjach z jednostką dysponującą atrybutem społecznie ją dyskredytującym. Zjawisko to dookreślane jest mianem stygmatyzacji przeniesionej (courtesy stigma), dla zaakcentowania możliwości rozszerzania się stygmatu, pierwotnie przypisywanego nosicielowi pewnych naznaczonych społecznie cech. Ma ono charakter złożony, co potwierdzają dotychczasowe doniesienia empiryczne (m.in. Ali i in. 2012; Mak, Cheung 2008). Złożoność ta jest wynikiem szeregu mechanizmów odpowiadających za postrzeganie innych, w tym przypadku rozpatrywanych w aspekcie relacyjnym. A wyraża się m.in. w różnorodności przejawów (na płaszczyźnie poznawczej, emocjonalnej, behawioralnej) oraz niejednoznaczności ich wzajemnych powiązań (MacRae 1999). Co istotne, nierzadko trudno jest precyzyjnie rozróżnić klarowne wskaźniki stygmatyzacji przeniesionej i aspekty stanowiące jej konsekwencję w osobowościowym i społecznym funkcjonowaniu jednostek (Parchomiuk 2010).

Stygmatyzacja przeniesiona odzwierciedla nasilone tendencje do znacznie uproszczonego, zgeneralizowanego postrzegania osób przez pryzmat ich powiązań z jednostką posiadającą atrybut stygmatyzujący. Jednocześnie zwiększa u nich prawdopodobieństwo takiego schematycznego postrzegania siebie, wartościowania własnego funkcjonowania i dokonywanych wyborów (Czykwin 2007). Przejawy stygmatyzacji przeniesionej oraz jej wielowymiarowe skutki rozpatrywane są w aspekcie zarówno postrzegania (felt stigma), jak i odczuwania (uwewnętrznienia społecznych sądów, ocen, w postaci np. wstydu, zażenowania, obsesyjnego lęku przed zachowaniami stygmatyzującymi) (enacted stigma) (Jacoby 2002). Dotychczasowe ustalenia empiryczne identyfikują tego typu przejawy stygmatyzacji przeniesionej u małżonków osób z chorobami przewlekłymi czy też z trwałą niepełnosprawnością (Goldstein, Johnson 1997; Hammell 1992). Wprawdzie intensywność stygmatu słabnie wraz z jego rozprzestrzenianiem się, niemniej nadal utrzymuje się na poziomie sprzyjającym wywoływaniu różnorodnych negatywnych zmian (Goffman 2007).

Obserwowane u współmałżonków osób z niepełnosprawnością ruchową zmiany na podłożu mechanizmów stygmatyzacji przeniesionej przyjmują różnorodną postać i wiążą się m.in.: z oczekiwaną redukcją roli do samej opieki przy jednoczesnej marginalizacji przymiotów dyktowanych relacją małżeńską; przyjęciem kategorii 
inności definiowanej przy udziale specyficznych cech partnera; poczuciem straty dotychczasowej tożsamości; ukształtowaniem tzw. lęku afiliacyjnego (przed podjęciem się na stałe roli opiekuna i kojarzeniem własnej osoby jedynie z tą rolą, a nie z indywidualnymi możliwościami i predyspozycjami); wytworzeniem się lęku przed stygmatem przeniesionym (byciem traktowanym jako osoba gorszej kategorii); czy też ze zwiększoną wrażliwością na przejawy zaciekawienia i niezrozumienia ze strony otoczenia (Angel, Buus 2011; Czykwin 2007; Goldstein, Johnson 1997; Shim i in. 2012). Uchwycono ponadto istnienie związku między stygmatyzacją przeniesioną a obciążeniem emocjonalnym, zmęczeniem, pogorszeniem zdrowia fizycznego i psychicznego, izolacją społeczną oraz negatywne korelacje z jakością życia u małżonków osób z niepełnosprawnością (Blanes i in. 2007; Borren i in. 2012; Post i in. 2005). Jednakże należy przy tym zaznaczyć, że wskazane powiązania podlegają mediowaniu i moderowaniu przez wiele czynników, co pozwala wnioskować o złożonym (i nie zawsze decydującym) oddziaływaniu stygmatyzacji przeniesionej na poszczególne przejawy psychospołecznego funkcjonowania tej grupy małżonków.

W kontekście przenoszenia cech poprzez skojarzenie, powiązanie z niepełnosprawną osobą, istotne znaczenie ma postrzeganie siebie ${ }^{1}$ i relacji małżeńskiej przez pełnosprawnego małżonka, specyficznie charakteryzowanego przez otoczenie. Przyjmując, że postrzeganie siebie kształtowane jest w większym lub mniejszym stopniu na bazie informacji dostarczanych od innych, można przewidywać jego powiązanie z przejawami stygmatyzacji przeniesionej. Podobnie relacyjność, znajdująca się u podłoża tego typu stygmatyzacji, może wyznaczać obraz relacji małżeńskiej z osobą naznaczoną stygmatem (deformacją ciała czy znacznymi ograniczeniami ruchowymi).

Dotychczasowe ustalenia w zakresie obrazu siebie osób poddawanych stygmatyzacji są niejednoznaczne i wskazują na różnorodne aspekty powiązań między tymi zmiennymi. W ramach przystosowywania się małżonka do nowej sytuacji życiowej po nabyciu trwałej niepełnosprawności przez partnera zwraca się uwagę na konieczność włączenia w obraz siebie cech bezpośrednio związanych z realizacją funkcji opiekuńczej. To swoiste poszerzenie obrazu siebie staje się nieodłącznym elementem pomyślnych efektów adaptacyjnych u pełnosprawnych małżonków (Post $\mathrm{i}$ in. 2005). Niemniej nadmierne eksponowanie cech związanych z opiekuńczością, przy jednoczesnym pomijaniu innych właściwości ukazujących indywidualne predyspozycje i możliwości, co może być konsekwencją nasilonej stygmatyzacji przeniesionej, wiąże się z niekorzystną modyfikacją obrazu siebie przez małżonka,

1 W przeglądzie wyników badań zostaną wykorzystane opracowania dotyczace szeroko pojętej oceny siebie u osób podlegających stygmatyzacji, przy świadomości braku zgodności zakresu znaczeniowego terminów tj. „postrzeganie siebie”, „obraz siebie”, „samoocena”. Badacze podejmujący tę problematykę nie zawsze bowiem jednoznacznie precyzują stosowane pojęcia lub też wskazują na ich wzajemne powiązania. 
ukierunkowaną na marginalizowanie znaczenia własnej indywidualności (Dickson $\mathrm{i}$ in. 2010).

Analizy w zakresie przeobrażeń w obrazie siebie pod wpływem stygmatyzacji dowodzą znaczenia stopnia uwewnętrznienia jej przejawów. Świadomość i zinternalizowanie stereotypowych przekonań, umacnianie samostygmatyzacji poprzez myślenie o sobie i zachowywanie się zgodnie ze społecznymi oczekiwaniami korespondowało z obniżoną samooceną (Corrigan i in. 2006; Dagnan, Waring 2004). Jennifer Crocker i Brenda Major (1989) wskazują, że jednostki przyjmujące stereotypowe przekonania na swój temat, jako obarczone stygmatem lub w jakiś sposób powiązane $\mathrm{z}$ atrybutami stygmatyzującymi, widzą rysy $\mathrm{w}$ obrazie siebie. Mogą się one przejawiać m.in. w postrzeganiu siebie jako niezdolnych do realizowania pewnych celów życiowych (Corrigan i in. 2009). Inni badacze sugerują z kolei, że obniżona samoocena i negatywne emocje mogą być traktowane jako wskaźniki utrwalonej samostygmatyzacji (Ali i in. 2012). Sprzyja ona wycofywaniu się z relacji społecznych, co w oczach innych utrwala negatywny status osoby stygmatyzowanej, który zwrotnie wzmacnia jej niekorzystny obraz siebie (Farzand, Abidi 2013; por. Zhang i in. 2014). Badacze wskazują w tym kontekście na bezpośredni udział negatywnego stereotypu w tworzeniu przekonań na własny temat przez osoby dysponujące cechami, które przez otoczenie są dyskredytowane (Corrigan i in. 2009). Potwierdzają to m.in. wyniki badań dowodzące niższej samooceny u osób postrzegających siebie i swoją sytuacją życiową jako stygmatyzującą (Hartman-Hall, Haaga 2002). Są one zgodne z kolei z poglądami Ervinga Goffmana (2007) wskazującymi, że osoby stygmatyzowane poprzez utożsamianie się z pewnymi narzuconymi standardami oceniania własnych warunków (kondycji, wyglądu, możliwości) w punkcie wyjścia wartościują siebie jako gorsze.

Jennifer Crocker i Brenda Major (1989) zaproponowały model wyjaśniający relację między stygmatyzacją a samooceną. Założyły, że osoby świadome negatywnego postrzegania przez innych - ze względu na przynależność do grupy stygmatyzowanej lub powiązanie z jednostką będącą nosicielem stygmatu - wykazują tendencję do włączania negatywnych społecznych atrybucji w obraz siebie, co w rezultacie prowadzi do obniżenia samooceny. Uwzględniając znaczenie porównania społecznego w doświadczaniu skutków stygmatyzacji, podkreślają jego moderującą rolę w relacji między percepcją przejawów stygmatyzujących a samooceną (por. Finlay, Lyons 2000). Dostrzeżona rola czynników pośredniczących w wyjaśnianiu związku między stygmatyzacją a samooceną ujawniła jego niezwykle złożony charakter. Ich mediujący lub moderujący udział pozwala w konsekwencji wytłumaczyć nie tylko zmodyfikowaną strukturę obrazu siebie u osób stygmatyzowanych, ale również wysoką samoocenę i pozytywne postrzeganie własnej osoby oraz swoich możliwości (Camp i in. 2002; Crocker, Major 1989; Sultan 2011). Na przykład pewne strategie radzenia sobie z reakcjami stygmatyzacyjnymi pełnią funkcję buforującą, nie dopuszczając do ich wpływu na obraz siebie u osób obarczonych stygmatem (Eccleston, Major 2006). 
Podsumowując, należy podkreślić, że mechanizmy, przez które stygmatyzacja oddziałuje na samoocenę osób jej poddawanych, mogą być następujące: a) samoocena jest obniżana w rezultacie włączenia stygmatyzujących reakcji innych w postrzeganie siebie; b) niska samoocena stanowi konsekwencję nie tylko przejawów stygmatyzujących, ale również strategii radzenia sobie z nimi przez daną osobę (Camp i in. 2002). Nie tyle zatem członkostwo w stygmatyzującej grupie bezpośrednio przekłada się na postrzeganie siebie, ile zinternalizowanie upowszechnionych, stereotypowych przekonań i stosowanie nieadaptacyjnych strategii zaradczych wobec przejawów stygmatyzacji tworzą warunki sprzyjające rozwijaniu się i umacnianiu negatywnych aspektów obrazu siebie.

Stygmatyzacja (w tym również przeniesiona) na bazie pewnych porównań społecznych pozostaje $\mathrm{w}$ związku nie tylko z ogólnie rozumianym postrzeganiem siebie, ale również z percepcją i oceną jakości swojego funkcjonowania w ramach pełnionych ról. Przejawy stygmatyzacji mogą pojawiać się szczególnie w wartościowaniu tych obszarów funkcjonowania, które dotyczą bezpośrednich, bliskich relacji społecznych. Należy do nich m.in. małżeństwo. Znaczenie stygmatyzacji przeniesionej dla przyjmowanego obrazu małżeństwa wyraża się głównie w oddziaływaniu społecznych przekonań na temat zachwiania roli (koncentracja na byciu opiekunem), nieuchronnego obniżenia jakości życia małżeńskiego i rodzinnego $\mathrm{z}$ racji posiadania stygmatu przez jednego $\mathrm{z}$ małżonków, wyrazistego zaburzenia relacji dawania - brania, a także jednokierunkowości udzielanego wsparcia (McPherson i in. 2011). Badania sugerują, że przyjęcie pierwotnej roli opiekuna przez małżonka osoby dysponującej atrybutem dyskredytującym (w tym przypadku jest to trwała niepełnosprawność lub choroba przewlekła) jest bezpośrednim czynnikiem wyznaczającym postrzeganie relacji małżeńskiej, swojego w niej miejsca i pełnionej roli (Dickson i in. 2010). Czynności opiekuńcze, często wynikające z poczucia obowiązku małżeńskiego, trwale wpisują się w obraz małżeństwa i nierzadko dominują w ocenie więzi między małżonkami (Dickson i in. 2010; Lucke i in. 2004). Badania prowadzone z udziałem współmałżonków osób z niepełnosprawnością ruchową wykazały, że więź małżeńska oparta jest bardziej na przyjaźni i sympatii niż intymności, i w większym stopniu jest relacją zależności (Chan 200o). W celu zabezpieczenia się przed kategoryzacją społeczną i zakwalifikowaniem do tzw. małżeństw innych, rodziny innej kategorii, identyfikowane są dążenia do normalizowania życia małżeńskiego i rodzinnego, utrzymywania sposobu funkcjonowania zbliżonego do społecznie narzuconego wzorca czy też podobnego do prowadzonego przed pojawieniem się choroby lub niepełnosprawności (Angel, Buus 2011; Eriksson, Svedlund 2006).

Dotychczasowa literatura z zakresu stygmatyzacji przeniesionej jedynie fragmentarycznie podejmuje kwestię postrzegania relacji małżeńskich przez współmałżonków osób dysponujących atrybutem odbiegającym od społecznie wyznaczonej normy. Na jej podstawie można przyjąć, że związek między tymi zmiennymi nie ma prostego, liniowego charakteru. Dostrzegana złożoność tego powiązania wynika 
przede wszystkim z niejednoznacznych konsekwencji stygmatyzacji przeniesionej dla psychospołecznego funkcjonowania małżonków, co ma znaczenie dla dokonywanych przez nich ocen własnego życia i bliskich relacji, w tym małżeńskiej. Dowodzą tego wyniki badań, wskazujące na różnorodne doświadczenia (pozytywne, ambiwalentne i negatywne) małżonków osób z chorobami przewlekłymi i niepełnosprawnościami, które wiążą się z odmiennym wartościowaniem relacji małżeńskiej (Shim i in. 2012). Podobnie jak w przypadku obrazu siebie, również w postrzeganiu małżeństwa istotne znaczenie może mieć stopień zinternalizowania stereotypowych przekonań na własny temat jako małżonka osoby niepełnosprawnej czy chorej. A w związku z tym, że te stereotypowe przekonania społeczne nie są jednolite (mogą wyrażać zarówno cechy pozytywne, negatywne, jak i ambiwalentne), znaczący jest nie tylko proces ich uwewnętrzniania, ale także przyjęcie ich określonej zawartości treściowej. Nie można w tym aspekcie pominąć roli zmiennych osobowościowych współmałżonka, czynników sytuacyjnych, rodzaju atrybutu społecznie dyskredytującego partnera, a także charakterystyk typowo socjodemograficznych. Przewidywany, niezwykle złożony charakter powiązań między stygmatyzacją przeniesioną a obrazem małżeństwa, jednie sygnalnie rozpatrywany w dotychczasowej literaturze, uzasadnia potrzebę badawczych rozstrzygnięć.

\section{Założenia badań własnych}

Celem podjętych badań było określenie znaczenia stygmatyzacji przeniesionej dla obrazu siebie oraz obrazu własnego małżeństwa u współmałżonków osób z nabytą niepełnosprawnością ruchową.

W strukturze stygmatyzacji przeniesionej uwzględniono wymiar postrzegany oraz odczuwany. Odzwierciedlają one dwojaką perspektywę doświadczeń: w pierwszym przypadku obserwowanych u niepełnosprawnego partnera w związku z negatywnymi reakcjami społecznymi, w drugim - relacjonowanych przez pełnosprawnego współmałżonka. W kategorii doświadczeń mieszczą się aspekty emocjonalne, behawioralne i poznawcze, dla potrzeb analiz własnych skoncentrowano się tylko na wskaźniku ogólnym, informującym o nasileniu stygmatyzacji w obu jej wymiarach.

Problematyka badawcza obejmowała dwie kwestie:

1. Ustalenie, czy poziom stygmatyzacji przeniesionej w jej wymiarze postrzeganym i odczuwanym różnicuje własności obrazu siebie współmałżonków osób z niepełnosprawnością (samokrytycyzm, tożsamość, akceptację, zachowanie, Ja fizyczne, Ja moralno-etyczne, Ja osobiste, Ja rodzinne i Ja społeczne), a jeśli tak, to w jaki sposób.

2. Ustalenie, czy poziom stygmatyzacji przeniesionej w jej wymiarze postrzeganym i odczuwanym różnicuje satysfakcję małżeńską partnerów pełnosprawnych w takich jej wymiarach, jak: intymność, samorealizacja, podobieństwo, rozczarowanie oraz globalnym. 
Literatura zawierająca wyniki badań dotychczas realizowanych w przedmiotowej problematyce pozwala postawić parę hipotez (por. Abraham i in. 2002; Angermeyer i in. 2003; Heijer den i in. 2011; Moses 2009; Noyman-Veksler i in. 2013; Phelan i in. 2011; Werner, Heinik 2008). W odniesieniu do pierwszego problemu zakłada się, że poziom stygmatyzacji w obu jej wymiarach będzie istotnie różnicował własności obrazu siebie pełnosprawnych współmałżonków. Oczekuje się, że w przypadku wyższego nasilenia stygmatyzacji wystąpi tendencja w kierunku większego samokrytycyzmu, słabszego poczucia tożsamości oraz niższego poziomu akceptacji i gorszej oceny siebie w różnych wymiarach, w tym: zachowania, obrazu ciała, postrzegania siebie jako osoby przestrzegającej norm moralno-etycznych, pojawią się słabsze poczucie odrębności i wartości oraz mniejsze przekonanie o posiadaniu przymiotów ważnych dla życia rodzinnego i społecznego funkcjonowania. Zakłada się, że niższe nasilenie stygmatyzacji postrzeganej i odczuwanej powiązane będzie z korzystniejszymi tendencjami w zakresie ewolucji obrazu siebie.

Istniejące dowody empiryczne, pokazujące wzrost obciążeń psychofizycznych związany z rolą współmałżonka - opiekuna osoby z niepełnosprawnością (Blake i in. 2003; Blonder i in. 2007; Chandler i in. 2007; Donelan i in. 2002; McCullagh i in. 2005; Parisé i in. 2013; Weitzenkamp i in. 1997), dają podstawę do sformułowania hipotezy mówiącej o istotnym znaczeniu stygmatyzacji postrzeganej i odczuwanej dla subiektywnego doświadczania przez badanych satysfakcji małżeńskiej. Przewiduje się, że jej wyższemu nasileniu będzie towarzyszyć mniejsze poczucie intymności w związku, słabsze przekonanie o możliwości samorealizacji oraz podejmowania wspólnych decyzji i działań w zakresie życia rodzinnego, a przy tym wyższe poczucie rozczarowania $z$ małżeństwa. Można również oczekiwać, że słabsze odczuwanie stygmatyzacji oraz rzadsze jej dostrzeganie wobec niepełnosprawnego partnera będą współwystępowały z wyższą satysfakcją ze związku.

W badaniach zastosowano Kwestionariusz Stygmatyzacji Przeniesionej autorstwa Stanisławy Byry i Moniki Parchomiuk, opracowany na podstawie Affiliate Stigma Scale (Winnie W.S. Mak i Rebekki Y.M. Cheung). Zbudowany jest on z 29 twierdzeń. Kwestionariusz pozwala określić nasilenie stygmatyzacji odczuwanej przez współmałżonka osoby z niepełnosprawnością oraz stygmatyzacji postrzeganej wobec osoby niepełnosprawnej ruchowo ze strony innych osób. Alfa Cronbacha dla skali stygmatyzacji postrzeganej wynosi o,93, a dla skali stygmatyzacji odczuwanej - 0,98. Ustalając poziomy stygmatyzacji przeniesionej w badanej grupie, posłużono się stenami (Brzeziński 2012).

Skala Samooceny (TSCS) Williama H. Fittsa, w polskiej wersji Janusza Kirenki, składa się ze 100 twierdzeń, które służą do opisu obrazu własnej osoby. Pozwala ona na określenie poziomu samooceny w następujących wymiarach: samokrytycyzmie, tożsamości, akceptacji, zachowaniu, Ja fizycznym, Ja moralno-etycznym, Ja osobistym, Ja rodzinnym i Ja społecznym.

Kwestionariusz Dobranego Małżeństwa (KDM-2) w opracowaniu Mieczysława Plopy i Jana Rostowskiego jest zbudowany z 32 twierdzeń. Na podstawie analizy 
czynnikowej ustalono cztery zmienne, w tym trzy pozytywne oraz jedną negatywną: intymność, rozczarowanie, samorealizację oraz podobieństwo. Kwestionariusz pozwala ocenić jakość związku małżeńskiego z perspektywy: możliwości realizacji potrzeb współmałżonków - bliskości, zaufania, oraz motywacji do pracy na rzecz wzmacniania związku i podnoszenia jego jakości; możliwości realizacji w związku swoich aspiracji i wartości przy jednoczesnym uzyskiwaniu satysfakcji; zgodności partnerów w zakresie realizacji istotnych celów małżeńskich oraz rodzinnych; rozczarowania związkiem, konkretyzowanego w postaci prób jego zerwania, braku przyjemności i satysfakcji, wzajemnego unikania i obniżenia poczucia odpowiedzialności za związek. Narzędzie posiada sprawdzone wskaźniki trafności oraz rzetelności, ponadto zostało poddane normalizacji (Plopa 2005).

Kwestionariusz własnej konstrukcji obejmował dane z zakresu charakterystyki osoby badanej (dane socjodemograficzne, subiektywną ocenę zdrowia) i jej współmałżonka z niepełnosprawnością ruchową (parametry niepełnosprawności).

Badana grupa liczyła 85 osób, w tym 60 mężczyzn (70,59\%). Średni wiek w latach wynosił 47,82. Badani w większości zamieszkiwali miasta: wojewódzkie - 32 osoby $(37,65 \%)$, powiatowe - 3 o badanych (35,29\%), małe - 16 (18,82\%), a tylko 7 osób $(8,23 \%)$ mieszkało na wsi. Wśród respondentów stosunkowo największy odsetek stanowiły osoby z wykształceniem średnim ( 35 osób, tj. 41,76\%) oraz wyższym (30 osób, tj. 35,39\%). W nielicznych przypadkach odnotowano wykształcenie policealne (3 osoby, tj. 3,53\%) i niepełne wyższe ( 2 osoby, tj. 2,35\%). Czterech badanych miało wykształcenie podstawowe (4,7\%), a jedenaście zawodowe (12,94\%).

Większość związków powstała przed nabyciem niepełnosprawności $(64, \mathrm{tj}$. 75,29\%), niemal jednakowo liczne były grupy małżeństw zawartych w trakcie choroby prowadzącej do niepełnosprawności (10, tj. 11,76\%) oraz po wystąpieniu niepełnosprawności (9, tj. 10,59\%). Czynniki etiologiczne nabytej niepełnosprawności ruchowej w badanej grupie obejmowały: uszkodzenie rdzenia kręgowego (34 przypadki, tj. 40\%), stwardnienie rozsiane (31, tj. 36,47\%), udar mózgu (17, tj. 20\%), amputację kończyn (3, tj. 3,53\%). Średni staż małżeński wynosił 22 lata.

\section{Wyniki badań własnych}

U badanych osób odnotowano wyższy poziom stygmatyzacji postrzeganej niż odczuwanej (tabela 1.). W większym zakresie obserwują one zatem niekorzystne reakcje - afektywne, behawioralne oraz poznawcze - u współmałżonków z niepełnosprawnością ruchową, niż doświadczają ich sami w związku z negatywnymi przejawami stygmatyzacji społecznej.

W rozkładzie wyników przeliczonych na normy stenowe wystąpiły zbliżone liczebności osób osiągających wyniki niskie, przeciętne i wysokie, co pozwoliło na zastosowanie analizy wariancji z jedną zmienną niezależną (ANOVA). 
Tabela 1. Nasilenie stygmatyzacji postrzeganej u badanych osób

\begin{tabular}{lccccc}
\hline \multirow{2}{*}{$\begin{array}{l}\text { wymiary } \\
\text { stygmatyzacji }\end{array}$} & $\mathrm{M}$ & $\mathrm{SD}$ & \multicolumn{3}{c}{ wyniki przeliczone } \\
\cline { 5 - 6 } \cline { 5 - 6 } postrzegana & 60,91 & 33,47 & $26(30,59 \%)$ & $32(37,64 \%)$ & $24(28,24 \%)$ \\
\hline odczuwana & 55,50 & 32,88 & $23(27,06 \%)$ & $33(38,82 \%)$ & $28(32,94 \%)$
\end{tabular}

M - średnie; SD - odchylenia standardowe

Tabela 2. Własności obrazu siebie u osób o różnym poziomie stygmatyzacji przeniesionej w wymiarze postrzeganym (ANOVA)

\begin{tabular}{|c|c|c|c|c|c|c|c|}
\hline & \multicolumn{3}{|c|}{ M } & \multicolumn{4}{|c|}{ LSD } \\
\hline & $\begin{array}{c}\text { niskie } \\
(1)\end{array}$ & $\begin{array}{c}\text { przeciętne } \\
\text { (2) }\end{array}$ & $\begin{array}{c}\text { wysokie } \\
(3)\end{array}$ & $\begin{array}{c}\mathrm{F} \\
\left(\mathrm{F}^{0}=2,78\right)\end{array}$ & $\mathrm{p}$ & grupy & $\mathrm{p}$ \\
\hline Samokrytycyzm & 29,46 & 31,00 & 33,35 & 3,44 & $0,037^{*}$ & $1-3$ & $0,011^{\star}$ \\
\hline Tożsamość & 88,08 & 91,22 & 95,87 & 4,230 & $0,018^{*}$ & $1-3$ & $0,005^{*}$ \\
\hline Akceptacja & 94,88 & 94,91 & 96,57 & 0,14 & 0,868 & - & - \\
\hline Zachowanie & 87,81 & 93,47 & 99,26 & 3,49 & $0,035^{\star}$ & $1-3$ & $0,011^{\star}$ \\
\hline Ja fizyczne & 52,42 & 54,97 & 59,39 & $\begin{array}{c}6,72 \\
0,002^{*}\end{array}$ & $\begin{array}{l}1-3 \\
2-3\end{array}$ & $\begin{array}{l}0,000^{*} \\
0,018^{*}\end{array}$ & \\
\hline $\begin{array}{l}\text { Ja moralno- } \\
\text {-etyczne }\end{array}$ & 54,08 & 55,41 & 57,96 & 2,39 & 0,098 & $1-3$ & $0,034^{*}$ \\
\hline Ja osobiste & 52,19 & 54,91 & 60,35 & 8,67 & $0,000^{*}$ & $\begin{array}{l}1-3 \\
2-3 \\
\end{array}$ & $\begin{array}{l}0,000^{*} \\
0,005^{*}\end{array}$ \\
\hline Ja rodzinne & 57,77 & 57,34 & 59,43 & 0,47 & 0,623 & - & - \\
\hline Ja społeczne & 54,08 & 56,81 & 58,00 & 1,54 & 0,219 & - & - \\
\hline
\end{tabular}

Poziom stygmatyzacji postrzeganej w sposób istotny różnicuje obraz siebie badanych w większości jego własności poddanych analizie (tabela 2). Osoby osiągające wysokie wyniki w tym wymiarze stygmatyzacji ujawniają najwyższy poziom samokrytycyzmu, ale jednocześnie najsilniejsze poczucie tożsamości. Uzyskują również najwyższe wyniki w zakresie oceny własnego zachowania, funkcjonowania fizycznego, moralno-etycznego oraz osobistego. Stwierdzono, że pod względem wskazanych własności obrazu siebie istotnie różnią się od osób o niskim poziomie stygmatyzacji postrzeganej. Odnotowano również istotne różnice pomiędzy 
osobami o niskiej i przeciętnej stygmatyzacji, ale tylko w obszarze Ja fizycznego i osobistego. Obie te własności obrazu siebie pozostają na wyższym poziomie u badanych o przeciętnym nasileniu stygmatyzacji postrzeganej. Nie stwierdzono różnicującego działania tej zmiennej w obszarze akceptacji siebie oraz oceny własnego Ja rodzinnego i społecznego.

Można zatem stwierdzić, że paradoksalnie częstsze dostrzeganie u niepełnosprawnego małżonka przekonań wiążących się z negatywnymi zachowaniami i reakcjami innych względem niego, negatywnych emocji, uczuć oraz zachowań z tym związanych towarzyszy specyficznej i niespodziewanej konfiguracji własności obrazu siebie. Odzwierciedla ona z jednej strony najwyższy samokrytycyzm i silną identyfikację z własnym Ja, a z drugiej - najwyższy poziom wartościowania siebie w odniesieniu do własnego zachowania, obrazu ciała, uznawania i realizacji zasad oraz wartości, posiadania przymiotów osobistych, takich jak: poczucie humoru, ugodowość, zdolność samoopanowania czy pozytywne nastawienie do innych.

Podobne tendencje, informujące o różnicującym działaniu zmiennej poziom stygmatyzacji, odnotowano w zakresie jej wymiaru odczuwanego (tabela 3.). Tylko w przypadku akceptacji siebie nie wystąpiła istotna różnica między grupami. Obserwowane w zakresie pozostałych własności obrazu siebie zróżnicowanie dotyczyło już nie tylko osób z niskim i wysokim poziomem stygmatyzacji, ale wszystkich przypadków, także jednostek z poziomem niskim i przeciętnym lub przeciętnym i wysokim.

Osoby o wysokim poziomie stygmatyzacji odczuwanej ujawniają najwyższy poziom samokrytycyzmu i siłę identyfikacji ze swoim Ja. Są najbardziej zadowolone i najwyżej oceniają własne zachowanie oraz własności fizyczne, osobowościowe i społeczne. Wyrażają najwyższy poziom satysfakcji ze swojej postawy moralno-etycznej, realizowanych wartości i zobowiązań rodzinnych czy kontaktów społecznych. W każdym ze wskazanych obszarów obrazu siebie różnią się istotnie od osób o niskim poziomie doświadczeń, będących konsekwencją stygmatyzacji społecznej. Stwierdzono również, że osoby ze stosunkowo najsilniejszą stygmatyzacją odczuwaną różnią się w zakresie poczucia tożsamości, oceny własnego zachowania, wartościowania siebie w płaszczyźnie fizycznej, moralno-etycznej i osobistej od tych badanych, u których poziom stygmatyzacji był przeciętny. W każdym przypadku wyższe nasilenie własności obrazu siebie odnotowano przy wysokim natężeniu stygmatyzacji.

Najniższy samokrytycyzm, najmniejsza satysfakcja z własnego wyglądu i troska o niego, najsłabsze przekonanie o posiadaniu cenionych cech osobowościowych, satysfakcjonującego życia rodzinnego i społecznego, obserwowane u osób o niskiej stygmatyzacji odczuwanej, różniły je istotnie od jednostek, u których nasilenie tej stygmatyzacji było przeciętne.

Podobnie zatem jak w przypadku stygmatyzacji postrzeganej mamy do czynienia $z$ tendencją niespodziewaną i sprzeczną z hipotezą. Okazuje się bowiem, że częstszym doświadczeniom poznawczym, afektywnym i behawioralnym, 
odzwierciedlającym przekonania o negatywnych reakcjach i zachowaniach otoczenia wobec pełnosprawnego partnera, towarzyszących im negatywnych emocjach i uczuciach oraz warunkowanych przez nie zachowaniach (jak unikanie społecznych kontaktów), towarzyszy najwyższy samokrytycyzm i siła identyfikacji z własnym Ja, a przy tym specyficzne charakterystyki Ja, z najsilniejszym ich wartościowaniem oraz poczuciem satysfakcji.

Tabela 3. Własności obrazu siebie u osób o różnym poziomie stygmatyzacji przeniesionej w wymiarze odczuwanym (ANOVA)

\begin{tabular}{|c|c|c|c|c|c|c|c|}
\hline & \multicolumn{4}{|c|}{ M } & & \multicolumn{2}{|c|}{ LSD } \\
\hline & $\begin{array}{c}\text { niskie } \\
\text { (1) }\end{array}$ & $\begin{array}{l}\text { przeciętne } \\
\text { (2) }\end{array}$ & $\begin{array}{l}\text { wysokie } \\
\text { (3) }\end{array}$ & $\begin{array}{c}\mathrm{F} \\
\left(\mathrm{F}^{0}=2,81\right)\end{array}$ & $\mathrm{p}$ & grupy & $\mathrm{p}$ \\
\hline Samokrytycyzm & 28,78 & 31,33 & 33,07 & 4,54 & $0,014^{\star}$ & $\begin{array}{l}1-3 \\
1-2\end{array}$ & $\begin{array}{l}0,004^{*} \\
0,067 \sim\end{array}$ \\
\hline Tożsamość & 87,13 & 90,39 & 97,75 & 9,71 & $0,000^{*}$ & $\begin{array}{l}1-3 \\
2-3\end{array}$ & $\begin{array}{l}0,000^{*} \\
0,002^{*}\end{array}$ \\
\hline Akceptacja & 91,22 & 96,94 & 97,21 & 1,90 & 0,156 & - & - \\
\hline Zachowanie & 86,26 & 93,03 & 99,79 & 5,45 & $0,006^{\star}$ & $\begin{array}{l}1-3 \\
2-3 \\
\end{array}$ & $\begin{array}{l}0,001^{*} \\
0,075^{\sim}\end{array}$ \\
\hline Ja fizyczne & 51,61 & 54,79 & 59,61 & 10,21 & O,000* & $\begin{array}{l}1-3 \\
2-3 \\
1-2 \\
\end{array}$ & $\begin{array}{l}0,000^{*} \\
0,004^{*} \\
0,071 \sim\end{array}$ \\
\hline $\begin{array}{l}\text { Ja } \\
\text { moralno-etyczne }\end{array}$ & 53,48 & 54,79 & 58,75 & 5,61 & $0,005^{\star}$ & $\begin{array}{l}1-3 \\
2-3\end{array}$ & $\begin{array}{l}0,002^{*} \\
0,012^{*}\end{array}$ \\
\hline Ja osobiste & 51,52 & 54,70 & 60,68 & 12,65 & $0,000^{*}$ & $\begin{array}{l}1-3 \\
2-3 \\
1-2\end{array}$ & $\begin{array}{l}0,000^{*} \\
0,001^{*} \\
0,084 \sim\end{array}$ \\
\hline Ja rodzinne & 55,04 & 59,06 & 59,86 & 2,73 & $0,071 \sim$ & $\begin{array}{l}1-3 \\
1-2\end{array}$ & $\begin{array}{l}0,031^{*} \\
0,061 \sim\end{array}$ \\
\hline Ja społeczne & 52,70 & 56,88 & 58,58 & 3,79 & $0,027^{*}$ & $\begin{array}{l}1-3 \\
1-2\end{array}$ & $\begin{array}{l}0,008^{*} \\
0,054 \sim\end{array}$ \\
\hline
\end{tabular}

M - średnie wartości dla podskal satysfakcji; F - test Fishera-Snedecora; LSD - test najmniejszych istotnych różnic; p - poziom istotności; ${ }^{\star}$ - istotne statystycznie; - zbliżone do istotnego

Stygmatyzacja postrzegana przez pełnosprawnych współmałżonków różnicuje odczuwaną przez nich satysfakcję ze związku w trzech wymiarach (tabela 4.). Osoby o niskim poziomie tej stygmatyzacji doświadczają największej intymności, częściej wyrażają przekonanie o udziale w decyzjach i działaniach, przy tym ich poczucie 
rozczarowania jest najmniejsze. W swojej ocenie życia małżeńskiego różnią się od osób o wysokim poziomie stygmatyzacji postrzeganej, u których tendencje obrazujące satysfakcję małżeńską są najmniej korzystne, w przypadku rozczarowania również od badanych o stygmatyzacji przeciętnie nasilonej. Nie stwierdzono różnicującego działania poziomu stygmatyzacji postrzeganej w przypadku globalnego wskaźnika satysfakcji oraz możliwości samorealizacji w związku.

Zgodnie z przewidywaniami partnerzy osób z niepełnosprawnością ruchową, dostrzegający u nich złożone skutki stygmatyzujących reakcji i zachowań otoczenia w najmniejszym nasileniu, korzystnie oceniają swój związek małżeński. Obserwuje się u nich najsilniejsze poczucie zaufania do partnera, bliskości, otwartości, szczęścia i miłości. Są to osoby w najwyższym stopniu przekonane, że można w związku osiągnąć porozumienie co do stosowania strategii zarządzania życiem rodzinnym. Jednostki te w najmniejszym stopniu odczuwają przy tym rozczarowanie związkiem, a zatem brak autonomii osobistej, przyjemności ze wspólnego przebywania i odpowiedzialności za związek. U osób, które stosunkowo najczęściej obserwują u niepełnosprawnych partnerów negatywne przekonania, emocje i uczucia oraz zachowania w konsekwencji niekorzystnych społecznych sytuacji, satysfakcja małżeńska w jej wymiarach pozytywnych jest najniższa, towarzyszy jej przy tym stosunkowo najwyższy poziom rozczarowania.

Tabela 4. Satysfakcja małżeńska u osób o różnym poziomie stygmatyzacji przeniesionej w wymiarze postrzeganym (ANOVA)

\begin{tabular}{lccccccc}
\hline & \multicolumn{3}{c}{$\mathrm{M}$} & \multicolumn{3}{c}{ LSD } \\
\cline { 2 - 8 } & $\begin{array}{c}\text { niskie } \\
(1)\end{array}$ & $\begin{array}{c}\text { przeciętne } \\
(2)\end{array}$ & $\begin{array}{c}\text { wysokie } \\
(3)\end{array}$ & $\begin{array}{c}\mathrm{F} \\
\left(\mathrm{F}^{0}=2,78\right)\end{array}$ & $\mathrm{p}$ & grupy & $\mathrm{p}$ \\
\hline Intymność & 28,92 & 28,19 & 25,78 & 2,47 & $0,091 \sim$ & $1-3$ & $0,036^{*}$ \\
\hline Rozczarowanie & 28,31 & 31,63 & 35,48 & 7,18 & $0,001^{*}$ & $\begin{array}{c}1-3 \\
2-3\end{array}$ & $\begin{array}{c}0,000^{*} \\
0,036^{*} \\
0,061 \sim\end{array}$ \\
\hline Samorealizacja & 24,62 & 24,72 & 24,39 & 0,05 & 0,948 & - & - \\
\hline Podobieństwo & 26,12 & 25,22 & 22,35 & 5,16 & $0,008^{*}$ & $1-3$ & $0,003^{*}$ \\
$2-3$ & $0,016^{*}$ \\
\hline Wynik ogólny & 108,19 & 109,75 & 108,09 & 0,21 & 0,810 & - & - \\
\hline
\end{tabular}

M - średnie wartości dla podskal satysfakcji; F - test Fishera-Snedecora; LSD - test najmniejszych istotnych różnic; p - poziom istotności; ${ }^{*}$ - istotne statystycznie; - zbliżone do istotnego

Tendencje opisane powyżej zaobserwowano w przypadku stygmatyzacji odczuwanej (tabela 5.). Jej różnicujące znaczenie odnotowano w trzech wymiarach 
małżeńskiej satysfakcji, nie wykazując przy tym istotnego działania w zakresie jej wyniku globalnego oraz samorealizacji.

Osoby z najniższym poziomem stygmatyzacji odczuwanej wykazują stosunkowo najwyższe poczucie intymności i podobieństwa oraz najniższe rozczarowanie ze związku. W tych zakresach różnią się od badanych $\mathrm{z}$ wysokim oraz przeciętnym nasileniem doświadczeń stygmatyzujących.

Można stwierdzić, że osobiste doświadczenia badanych, obejmujące przekonania o byciu podmiotem negatywnych reakcji społecznych i zachowań, wskazujących na stygmatyzację przeniesioną, emocje i uczucia czy też zachowania powiązane z tymi przekonaniami, niekorzystne dla jednostki, powodujące jej obciążenie psychofizyczne, wiążą się z tendencją do negatywnego oceniania swojego małżeństwa jako pozbawionego miłości, bliskości i szczęścia, przynoszącego rozczarowanie i chęć wycofania. Obniżenie nasilenia przekonań, emocji, uczuć i zachowań, stanowiących skutek negatywnych społecznych sytuacji, łączy się z najbardziej pozytywnym obrazem małżeństwa.

Tabela 5. Satysfakcja małżeńska u osób o różnym poziomie stygmatyzacji przeniesionej w wymiarze odczuwanym (ANOVA)

\begin{tabular}{lccccccc}
\hline & \multicolumn{3}{c}{$\mathrm{M}$} & & \multicolumn{2}{c}{ LSD } \\
\cline { 2 - 7 } & $\begin{array}{c}\text { niskie } \\
(1)\end{array}$ & $\begin{array}{c}\text { przeciętne } \\
(2)\end{array}$ & $\begin{array}{c}\text { wysokie } \\
(3)\end{array}$ & $\begin{array}{c}\mathrm{F} \\
\left(\mathrm{F}^{0}=2,80\right)\end{array}$ & $\mathrm{p}$ & grupy & $\mathrm{p}$ \\
\hline Intymność & 30,00 & 27,15 & 26,22 & 3,68 & $0,029^{*}$ & $\begin{array}{c}1-2 \\
1-3\end{array}$ & $\begin{array}{c}0,042^{*} \\
0,011^{*}\end{array}$ \\
\hline Rozczarowanie & 26,35 & 33,03 & 34,70 & 12,41 & $0,000^{*}$ & $\begin{array}{c}1-2 \\
1-3\end{array}$ & $0,000^{*}$ \\
\hline Samorealizacja & 24,78 & 24,42 & 24,74 & 0,08 & 0,919 & - & - \\
\hline Podobieństwo & 27,04 & 24,52 & 22,89 & 5,95 & $0,004^{*}$ & $\begin{array}{c}1-2 \\
1-3\end{array}$ & $0,032^{*}$ \\
\hline Wynik ogólny & 108,43 & 109,12 & 108,63 & 0,03 & 0,971 & - & - \\
\hline
\end{tabular}

M - średnie wartości dla podskal satysfakcji; F - test Fishera-Snedecora; LSD - test najmniejszych istotnych różnic; p - poziom istotności; * - istotne statystycznie; - zbliżone do istotnego

\section{Podsumowanie i dyskusja}

Celem opisanych badań było określenie znaczenia stygmatyzacji przeniesionej postrzeganej oraz odczuwanej dla wybranych własności obrazu siebie oraz satysfakcji z małżeństwa u współmałżonków osób z niepełnosprawnością ruchową. Uzyskane wyniki potwierdziły, że poziom tej stygmatyzacji ma istotne znaczenie 
różnicujące w zakresie obu zmiennych, jakkolwiek siła i kierunek tego działania nie są jednolite dla poszczególnych ich wskaźników.

Stygmatyzacja postrzegana wobec partnera - osoby niepełnosprawnej - ma nieco mniejsze znaczenie niż odczuwana w różnicowaniu własności obrazu siebie pełnosprawnej osoby, jeśli uwzględni się zakres istotnych różnic. Ustalone w obu wymiarach stygmatyzacji tendencje są jednak zbieżne w aspekcie kierunku różnicowania. Mają przy tym specyficzny i niezgodny z hipotetycznie przyjmowanym charakter. Uzyskane konfiguracje własności obrazu siebie nie są jednoznaczne pod względem specyfiki. W przypadku osób o wysokiej stygmatyzacji postrzeganej i odczuwanej konfigurację taką tworzy wysoki samokrytycyzm (zgodnie z przewidywaniami) i silne poczucie tożsamości, a przy tym stosunkowo najwyższa ocena poszczególnych aspektów Ja. Przy żadnym wymiarze stygmatyzacji nie obserwuje się jej istotnego powiązania $\mathrm{z}$ samoakceptacją jednostki pełnosprawnej. Wymiar stygmatyzacji postrzeganej nie ma również znaczenia dla wartościowania siebie w sferze rodzinnej czy społecznej.

Wyjaśniając ustalone tendencje, można nawiązać do zjawiska opisanego w kontekście samostygmatyzacji - paradoksu, polegającego na zachowaniu własności obrazu siebie czy też ich poprawie w obliczu stygmatyzujących doświadczeń. Obraz siebie jest traktowany w kategoriach zasobów zaradczych, uruchamianych w sytuacjach stresowych, a za takowe można uznać sytuacje stygmatyzacji. Być może mamy tu do czynienia ze swoistą mobilizacją zasobów w obliczu zwiększonego nasilenia stygmatyzujących doświadczeń.

Stosunkowo najwyższy poziom samokrytycyzmu może wskazywać na większą wnikliwość w zakresie samoobserwacji, być może wrażliwość na społeczne sygnały, co z kolei rodzi silniejszą tendencję do postrzegania i odczuwania stygmatyzacji. W obu wymiarach ma ona bowiem charakter subiektywny i stanowi efekt przepracowania społecznych sygnałów przez pryzmat posiadanych cech osobowościowych.

Zarówno stygmatyzacja postrzegana, jak i odczuwana różnicuje satysfakcję ze związku małżeńskiego w przewidywany sposób. Ustalona tendencja jest zbieżna w swoim charakterze w zakresie obu wymiarów. Niższej stygmatyzacji towarzyszy korzystniejszy obraz związku, ze stosunkowo najsilniejszym poczuciem intymności i podobieństwa oraz najsłabszym rozczarowaniem. Nie stwierdzono, aby poziom stygmatyzacji postrzeganej i odczuwanej miał istotne znaczenie dla samorealizacji pełnosprawnych partnerów.

Poszukując uzasadnienia dla uzyskanych rezultatów, zgodnych z przyjętą hipotezą, należy odwołać się do istoty relacji małżeńskiej oraz jej specyfiki w sytuacji niepełnosprawności partnera. Zarówno osobiste doświadczenia stygmatyzacji, jak też ich zwiększone nasilenie obserwowane u niepełnosprawnego współmałżonka mogą być źródłem obciążeń psychofizycznych, związanych z przewidywaniem społecznego odrzucenia i unikania, dyskryminowania w różnych sytuacjach życia codziennego, wzbudzanym poczuciem winy wobec osoby niepełnosprawnej, której nie można ochronić przed negatywnymi reakcjami społecznymi. Doświadczanie 
stygmatyzacji oraz jej postrzeganie wiązać się mogą z redukcją społecznych zasobów, jako skutkiem unikania sytuacji społecznej ekspozycji oraz wycofania $z$ różnych ról i zadań. $Z$ drugiej strony, obciążenie opieką, przy jednoczesnym zredukowaniu możliwości realizacji potrzeb własnych, może rzutować na osłabienie poczucia satysfakcji z życia, w tym rodzinnego i małżeńskiego, zwiększać subiektywne przewidywanie stygmatyzacji, nawet przy braku jej obiektywnych przejawów.

\section{Bibliografia}

Abraham C., Gregory N., Wolf L., Pemberton R. (2002). Self-esteem, stigma and community participation amongst people with learning difficulties living in the community. "Journal of Community and Applied Social Psychology”, 12 (6), s. 430-443.

Ali A., Hassiotis A., Strydom A., King M. (2012). Self stigma in people with intellectual disabilities and courtesy stigma in family careers: a systematic review. „Research in Developmental Disabilities”, 33 (6), s. 2122-2140.

Angel S., Buus N. (2011). The experience of being a partner to a spinal cord injured person: a phenomenological-hermeneutic study. „International Journal of Qualitative Studies on Health and Well-being", 6 (4), s. 1-11.

Angermeyer M.C., Schulze B., Dietrich S. (2003). Courtesy stigma. A focus group study of relatives of schizophrenia patients. „Social Psychiatry and Psychiatric Epidemiology", 38 (10), s. 593-602.

Blake H., Lincoln N.B., Clarke D.D. (2003). Caregiver strain in spouses of stroke patients. „Clinical Rehabilitation”, 17 (3), s. 312-317.

Blanes L., Carmagnani M.I.S., Ferreira L.M. (2007). Health-related quality of life of primary caregivers of persons with paraplegia. "Spinal Cord”, 45 (6), s. 399-403.

Blonder L.X., Langer S.L., Pettigrew L.C., Garrity T.F. (2007). The effects of stroke disability on spousal caregivers. „NeuroRehabilitation”, 22 (2), s. 85-92.

Borren I., Tambs K., Idstad M., Ask H., Sundet J.M. (2012). Psychological distress and subjective well-being in partners of somatically ill or physically disabled: the Nord-Trøndelag Health Study. „Scandinavian Journal of Psychology”, 53 (6), s. 475-482.

Brzeziński J. (2012). Metodologia badań psychologicznych. Warszawa: Wydawnictwo Naukowe PWN.

Camp D., Finlay W.M., Lyons E. (2002). Is low self-esteem an inevitable consequence of stigma? An example from women with chronic mental health problems. „Social Science and Medicine", 55 (5), 823-834.

Chan R.C. (2000). How does spinal cord injury affect marital relationship? A story from sides of the couple. „Disability and Rehabilitation”, 22 (17), s. 764-775. 
Chandler M., Kennedy P., Sandhu N. (2007). The association between threat appraisals and psychological adjustment in partners of people with spinal cord injuries. „Rehabilitation Psychology”, 52 (4), s. 470-477.

Corrigan P.W., Larson J.E., Rüsh N. (2009). Self-stigma and the „why try” effect: impact on life goals and evidence-based practices. „World Psychiatry”, 8 (2), s. 75-81.

Corrigan P.W., Watson A.C., Baar L. (2006). The self-stigma of mental illness: implications for self-esteem and self-efficacy. „Journal of Social and Clinical Psychology", 25 (8), s. 875-884.

Crocker J., Major B. (1989). Social stigma and self-esteem: the self-protective properties of stigma. „Psychological Review”, 96 (4), s. 608-630.

Czykwin E. (2007). Stygmat społeczny. Warszawa: PWN.

Dagnan D., Waring M. (2004). Linking stigma to psychological distress: testing a social-cognitive model of the experience of people with intellectual disabilities. "Clinical Psychology and Psychotherapy”, 11 (4), s. 247-254.

Dickson A., O’Brien G., Ward R., Allan D., O'Carroll R. (2010). The impact of assuming the primary caregiver role following traumatic spinal cord injury: an interpretative phenomenological analysis of the spouse's experience. „Psychology and Health", 25 (9), s. 1101-1120.

Donelan K., Hill C.A., Hoffman C., Scoles K., Feldman P.H., Levine C., Gould D. (2002). Challenged to care: informal caregivers in a changing health system. „Health Aff (Millwood)”, 21 (4), s. 222-231.

Eccleston C.P., Major B.N. (2006). Attributions to discrimination and self-esteem: the role of group identification and appraisals. „Group Processes and Intergroup Relations", 9 (2), s. 147-162.

Eriksson M., Svedlund M. (2006). 'The intruder': spouses' narratives about life with a chronically ill partner. "Journal of Clinical Nursing”, 15 (3), s. 324-333.

Farzand M., Abidi M. (2013). Effects of mental illness stigma on social identity and social isolation among family caregivers of psychiatric patients. „International Journal of Medical and Pharmaceutical Sciences”, 4 (1), s. 31-40.

Finlay W.M., Lyons E. (2000). Social categorizations, social comparisons, and stigma: presentations of self in people with learning difficulties. "The British Journal of Social Psychology", 39 (Pt 1), s. 129-146.

Goffman E. (2007). Piętno. Rozważania o zranionej tożsamości. Gdańsk: GWP.

Goldstein S.B., Johnson V.A. (1997). Stigma by association: perceptions of the dating partners of college students with physical disabilities. „Basic and Applied Social Psychology", 19 (4), s. 495-504.

Hammell K.R.W. (1992). The caring wife: the experience of caring for a severely disabled husband in the community. „Disability and Society”, 7 (4), s. 349-362.

Hartman-Hall H.M., Haaga D.A. (2002). College student's willingness to seek help for their learning disabilities. „Learning Disability Quarterly”, 25 (4), s. 263-274.

Heijer den M., Seynaeve C., Vanheusden K., Duivenvoorden H.J., Vos J., Bartels C.C., Menke-Pluymers M.B., Tibben A. (2011). The contribution of self-esteem 
and self-concept in psychological distress in women at risk of hereditary breast cancer. „Psychooncology”, 20 (11), s. 1170-1175.

Jacoby A. (2002). Stigma, epilepsy, and quality of life. „Epilepsy and Behavior”, 3 $\left(6 \mathrm{~S}_{2}\right), 10-20$.

Lucke K.T., Coccia H., Goode J.S., Lucke J.F. (2004). Quality of life in spinal cord injured individuals and their caregivers during the initial 6 months following rehabilitation. „Quality of Life Research”, 13 (1), s. 97-110.

MacRae H. (1999). Managing courtesy stigma: the case of Alzheimer's disease. "Sociology of Health and Illness”, 21 (1), s. 54-70.

Mak W.W., Cheung R.Y. (2008). Affiliate stigma among caregivers of people with intellectual disability or mental illness. „Journal of Applied Research in Intellectual Disabilities", 21 (6), s. 532-545.

McCullagh E., Brigstocke G., Donaldson N., Kalra L. (2005). Determinants of caregiving burden and quality of life in caregivers of stroke patients. „Stroke”, 36 (10), s. 2181-2186.

McPherson Ch.J., Wilson K.G., Chyurlia L., Leclerc Ch. (2011). The caregiving relationship and quality of life among partners of stroke survivors: a cross-sectional study. „Health and Quality of Life Outcomes”, 9 (29), DOI: 10.1186/1477-7525-9-29.

Moses T. (2009). Stigma and self-concept among adolescents receiving mental health treatment. „American Journal of Orthopsychiatry”, 79 (2), s. 261-274.

Noyman-Veksler G., Weinberg D., Fennig S., Davidson L., Shahar G. (2013). Perceived stigma exposure in schizophrenia: the key role of self-concept clarity. "Self and Identity”, 12 (6), s. 663-674.

Parchomiuk M. (2010). Stygmatyzacja przeniesiona - analiza zjawiska w odniesieniu do rodzin osób niepetnosprawnych i chorych. „Annales Universitatis Mariae Curie-Skłodowska”, t. 23, s. 55-69.

Parisé H., Laliberté F., Lefebvre P., Duh M.S., Kim E., Agashivala N., Abouzaid S., Weinstock-Guttman B. (2013). Direct and indirect cost burden associated with multiple sclerosis relapses: excess costs of persons with MS and their spouse caregivers. "Journal of the Neurological Sciences", 330 (1/2), s. 71-77.

Phelan S.M., Griffin J.M., Hellerstedt W.L., Sayer N.A., Jensen A.C., Burgess D.J., Ryn van M. (2011). Perceived stigma, strain, and mental health among caregivers of veterans with traumatic brain injury. „Disability and Health Journal”, 4 (3), s. $177-184$.

Plopa M. (2005). Więzi w matżeństwie i rodzinie. Metody badań. Kraków: Oficyna Wydawnicza Impuls.

Post M.W., Bloemen J., Witte de L.P. (2005). Burden of support for partners of persons with spinal cord injuries. „Spinal Cord”, 43 (5), s. 311-319.

Shim B., Barroso J., Davis L.L. (2012). A comparative qualitative analysis of stories of spousal caregivers of people with dementia: negative, ambivalent, and positive experiences. „International Journal of Nursing Studies”, 49 (2), s. 220-229. 
Sultan S. (2011). Stigmatization: addressing self-esteem and personal growth in patients with psychological and physiological illness. „Pakistan Journal of Social Sciences", 31 (1), s. 29-36.

Weitzenkamp D.A., Gerhart K.A., Charlifue S.W., Whiteneck G.G., Savic G. (1997). Spouses of spinal cord injury survivors: the added impact of caregiving. „Archives of Physical Medicine and Rehabilitation", 78 (8), s. 822-827.

Werner P., Heinik J. (2008). Stigma by association and Alzheimer's disease. „Aging and Mental Health", 12 (1), s. 92-99.

Zhang L., Li W., Liu B., Xie W. (2014). Self-esteem as mediator and moderator of the relationship between stigma perception and social alienation of Chinese adults with disability. „Disability and Health Journal”, 7 (1), s. 119-123.

\title{
SELF-CONCEPT AND IMAGE OF MARRIAGE IN PERCEPTION OF SPOUSES OF INDIVIDUALS WITH MOBILITY DISABILITY. ROLE OF COURTESY STIGMA
}

\begin{abstract}
The paper analyzes the results of the author's own research on the significant role played by courtesy stigma in the concept of self and marital satisfaction among spouses of individuals with a mobility disability. Considering the global level of courtesy stigma (perceived and enacted), its significance for selected characteristics of the self-concept among the non-disabled spouses, as well as for their marital satisfaction in specific aspects and generally, was analyzed. The sample consisted of 85 non-disabled individuals. The material for analysis was obtained using the Courtesy Stigma Questionnaire developed by the author, as well as Tennessee Self-Concept Scale by W. H. Fitts and the Well-Matched Marriage Questionnaire by M. Plopa. The level of courtesy stigma, in both aspects, was found to significantly differentiate characteristics of respondents' concept of self and marital satisfaction. Individuals with high levels of stigma revealed relatively the highest level of self-criticism and identification with the self, but also ascribed the highest value to specific aspects of the self. The most positive image of a marital relationship with the relatively highest feeling of intimacy and similarity, and at the same time, the lowest disappointment levels, was found among individuals with low levels of stigma (perceived and enacted).
\end{abstract}

Key words: stigmatization, courtesy stigma, self-concept, marital satisfaction, physical disability

Monika Parchomiuk - doktor habilitowana, adiunkt w Zakładzie Socjopedagogiki Specjalnej Wydziału Pedagogiki i Psychologii Uniwersytetu Marii Curie-Skłodowskiej w Lublinie. Autorka publikacji: Postawy pedagogów specjalnych wobec seksualności osób $z$ niepetnosprawnościa intelektualna (2013), Osobiste i rodzinne korelaty aktywności zawodowej matek dzieci z niepetnosprawnościa (2011), współautorka monografii Edukacja i rehabilitacja osób z upośledzeniem umysłowym (2008). Adres do korespondencji: ul. Narutowicza 12, 20-004 Lublin. Adres e-mail: monika.parchomiuk@poczta.umcs.lublin.pl. 
Stanisława Byra - doktor habilitowana, adiunkt w Zakładzie Metodologii Nauk Pedagogicznych Wydziału Pedagogiki i Psychologii Uniwersytetu Marii Curie-Skłodowskiej w Lublinie. Autorka publikacji: Przystosowanie do życia z niepetnosprawnościa ruchowa $i$ choroba przewlekła. Struktura i uwarunkowania (2012), współautorka monografii Stereotypy niepelnosprawności (2010) oraz Zasoby osobiste w chorobach psychosomatycznych (2011). Adres do korespondencji: ul. Narutowicza 12, 20-004 Lublin. Adres e-mail: stanislawa.byra@poczta.umcs.lublin.pl. 